\title{
The British Empire and Commonwealth in World War II: Selection and Omission in English History Textbooks
}

\author{
Stuart Foster, Institute of Education. University of London
}

\begin{abstract}
The study of history through school textbooks arguably is still the predominant medium for classroom learning in England. History textbooks are a powerful influence upon the development of the attitudes, values, perceptions and understanding of young citizens. Nowhere is the role of textbooks in personal orientation more pronounced than in textbooks on the Second World War. The paper analyses the overt and implicit messages that such textbooks present to their readers. The conclusion is pessimistic; textbooks are Anglo-centric within a Euro-centric and Caucasian world picture. They need to reflect a sensitive picture of race and ethnicity, and the relative roles and importance of the nationalities and communities that were actively engaged in the struggle against the Axis powers. As such, they should positively represent the rich and diverse stories of all races that research has revealed to have played a seminal role in The Second World War.
\end{abstract}

\section{Keywords}

British Commonwealth, British Empire, Citizenship, English History, History teaching, Identity, Nationalism, Racism, The Second World War, History textbooks

\section{Introduction}

The Second World War stands as the most devastating and destructive conflict in human history. To a degree never experienced by previous generations it was a war that blurred the distinction between combatant and non-combatants, that mobilised the vast human, economic, and technological resources of entire populations, and that legitimised ferocious and brutal assaults on civilians. Estimates suggest that a staggering 60 million people lost their lives during the Second World War as more than 1 trillion dollars was expended on the conflict. The economic, political, social, and economic consequences of the war were profound. In political terms alone, World War II led to a seismic shift in the status and influence of the world's major powers. It ushered in a new era of superpower conflict between the United States and the Soviet Union, accelerated the decline of the French and British empires, precipitated the appearance of new democratic governments in Germany and Japan, and witnessed the emergence of communist China.

On a scale equally unprecedented in human history the war was a truly global event. More than 60 nations representing 1.7 billion people or three quarters of the world's population were consumed by the conflict. Military actions raged in Asia, Africa, Europe, and on the world's major oceans. The war engaged citizens from Argentina to India, Australia to Iran, and Thailand to Kenya. Few peoples of the world remained beyond the ruinous grip of war. Understandably, therefore, the Second World War typically stands as a landmark episode in history education throughout the world. In England its inclusion in the history curriculum is assured and the presence of the Second World War in history textbooks guaranteed.

Significantly, however, despite the global sweep of the war, analysis of textbooks commonly used in England suggests that schoolbooks devote almost exclusive attention to the 'principal' Allied and Axis powers. Accordingly, the actions of Britain, USA, and the USSR, routinely are portrayed fighting the Axis powers of Germany, Japan, and to a lesser extent, Italy. However, although textbooks acknowledge the broad geographical reach of the war, few books offer sustained attention to the contributions of nations and peoples beyond the 'major powers'. In some respects focus on the Allied and Axis nations is understandable. For example, the human cost 
of the war fell heaviest on the Soviet Union who suffered the loss of approximately 20 million people. Economically the United States spent more on the war than any other nation and Britain and her Empire and Commonwealth committed more than ten million troops to active combat. Equally the part played by Japan and Germany in precipitating the war in the respective Pacific and European theatres and their combined commitment of more than 11 million troops demonstrate their central role in the conflict.

Nevertheless, although some justification can be made for primary focus on the major Allied and Axis powers, the widespread absence from textbooks of other nations, cultures, and ethnic groups determines that history students will learn about the war from a disturbingly limited and narrow perspective. Absent from their understanding of the war will be any knowledge of the contributions of other nations and any sensitivity to the accomplishments, actions, and complex perspectives of peoples from other diverse cultural and national backgrounds. Indeed the apparent omission of perspectives other than those traditionally considered mainstream illuminates serious deficiencies in contemporary history education.

To explore these issues more fully this study is broadly divided into four parts. First, through story line, content, and pictorial analysis four contemporary history textbooks routinely used in history classrooms in England are analysed. Although analysis focuses on portrayals of people from the British Empire and Commonwealth, primary focus is placed on the manner and extent to which peoples from India, Africa, and the Caribbean feature in textbook representations of the Second World War. Second, based on the findings of relevant historical scholarship, attention is drawn to the experiences of colonial peoples during World War II. Third, the study illuminates and explains the reasons for the apparent gulf between the historical record and the information contained in history textbooks. Finally some broader suggestions for ensuring the emergence of a more inclusive history education are offered.

\section{Portrayal of peoples from the Empire and Commonwealth in history textbooks}

\section{Textbook sample}

Following a wide-ranging review of secondary history textbooks currently available on the market in England, textbooks were selected for analysis that met four criteria which required that the textbook (a) was designed to support study in a Modern World GCSE History course ${ }^{1}$ (b) devoted prominent sections or chapters to the study of the Second World War (c) was produced by a major publishing house and was widely adopted in schools throughout England, and (d) was published since 2001 (see Fig. 1).

\begin{tabular}{|l|l|l|l|l|}
\hline \multicolumn{1}{|c|}{ Author(s) } & Principal Title & Publisher & Total Pages & Publication Year \\
\hline $\begin{array}{l}\text { David Ferriby \& } \\
\text { Jim McCabe }\end{array}$ & $\begin{array}{l}\text { Modern World } \\
\text { History }\end{array}$ & Heinemann & 288 & 2002 \\
\hline Tom McAleavy & $\begin{array}{l}\text { Modern World } \\
\text { History }\end{array}$ & $\begin{array}{l}\text { Cambridge } \\
\text { University Press }\end{array}$ & 273 & 2004 \\
\hline Allan Todd & $\begin{array}{l}\text { The Modern } \\
\text { World }\end{array}$ & $\begin{array}{l}\text { Oxford } \\
\text { University Press }\end{array}$ & 304 & 2001 \\
\hline Ben Walsh & $\begin{array}{l}\text { GCSE Modern } \\
\text { World History }\end{array}$ & John Murray & 427 & 2001 \\
\hline
\end{tabular}

\footnotetext{
${ }^{1}$ The General Certificate of Secondary Education (GCSE) course is a two-year examination course for students aged 14 to 16 . The GCSE is taken in individual subject areas and assessed at national level by one of four independent examination boards. The Modern World History course is among the most popular GCSE courses adopted in secondary schools throughout England.
} 
Figure 1: The four textbooks selected for analysis.

\section{Analysis}

Drawing on the author's previous research studies (e.g., Nicholls and Foster, 2005; Foster and Nicholls, 2005; Foster, 1999; Foster and Rosch, 1997; Foster, Morris, and Davis; 1996; Foster and Morris 1995) and methodological considerations raised by other scholars in the field of textbook research (e.g., Foster and Crawford, in press; Schissler and Soysal, 2005; Nicholls, 2003; Crawford, 2000; Hein and Selden, 2000; Pingel, 1999; Apple and Christian-Smith, 1991; Schissler, 1990; Bergahn and Schissler, 1987) textbooks in this study principally were analysed using story line, content and pictorial analysis. Primary attention was given to qualitative analysis; however, quantitative measures were used to explore the relative emphases of selected areas of content (e.g., the number of visual images devoted to the actions of troops from the Empire and Commonwealth or the priority given to the study of World War II relative to other events of the twentieth century).

Guiding research questions used for these analyses focused on three overreaching and interrelated issues:

1. How, in what way, and to what extent does the Second World War feature in Modern World History textbooks typically used in England?

2. What key topics, events and theatres of war typically receive most prominent attention?

3. How, in what way, and to what extent are the experiences of peoples from the Empire and Commonwealth portrayed in textbook narratives and photographic representations?

\section{Results}

1. How, in what way, and to what extent does the Second World War feature in Modern World History textbooks typically used in England?

Without exception all four modern world history textbooks cover the twentieth century from the causes of World War I to global events in the late 1980s and the early 1990s (e.g., the break up of the Soviet Union, demonstrations in Tiananmen Square, the end of Apartheid). As indicated by the chart below (Fig. 2), on average the Second World War accounts for between $7.32 \%$ and $12.5 \%$ of textbook coverage. The number of pages devoted specifically to the war ranges from 20 to 38 with discrete chapters assigned to the subject a common feature. For the most part the Second World War is considered an essential component of twentieth century study and holds a status similar to that of other popular topics such as: Russia and the USSR 1900-1941; Germany 1918-1945; USA between the wars; and The Cold War. Although some difference in the way the war is presented exists (e.g., one book focuses on Britain and the Second World War, whereas another sets World War II in the context of international relations 1919-1989), it is abundantly clear that World War II enjoys a prominent position. Indeed, if analytical coverage of World War II was extended to include the causes of the Second World War in some books it would occupy more pages than any other twentieth century topic (e.g., in Ben Walsh's book coverage would constitute 63 pages or $14.75 \%$ of the total). 


\begin{tabular}{|c|c|c|c|c|}
\hline Authors(s) & Principal Title & Chapters or Sections & $\begin{array}{l}\text { Pages } \\
\text { devoted to } \\
\text { WWII }\end{array}$ & $\begin{array}{l}\text { WWII pages } \\
\text { as \% of total } \\
\text { book }\end{array}$ \\
\hline $\begin{array}{l}\text { David Ferriby } \\
\text { \& Jim McCabe }\end{array}$ & $\begin{array}{l}\text { Modern World } \\
\text { History }\end{array}$ & $\begin{array}{l}\text { Chapter 3: Britain and the } \\
\text { Second World War }\end{array}$ & $\begin{array}{c}\text { pp. } 121- \\
147 \\
26 \text { pages }\end{array}$ & $9.02 \%$ \\
\hline Tom McAleavy & $\begin{array}{l}\text { Modern World } \\
\text { History }\end{array}$ & $\begin{array}{l}\text { International Relations } \\
1919-1989 \text { (pages from } \\
\text { Nazi-Soviet Pact to Fall of } \\
\text { European Empires }\end{array}$ & $\begin{array}{l}\text { pp. } 74-94 \\
20 \text { pages }\end{array}$ & $7.32 \%$ \\
\hline Allan Todd & $\begin{array}{l}\text { The Modern } \\
\text { World }\end{array}$ & $\begin{array}{l}\text { Chapter 9: The Second } \\
\text { World War and Chapter } \\
\text { 10: Britain and the } \\
\text { Second World War }\end{array}$ & $\begin{array}{c}\text { pp. } 148- \\
186 \\
38 \text { pages }\end{array}$ & $12.5 \%$ \\
\hline Ben Walsh & $\begin{array}{l}\text { GCSE Modern } \\
\text { World History }\end{array}$ & $\begin{array}{l}\text { A. Chapter 10: The } \\
\text { World at War 1939- } \\
1945\end{array}$ & $\begin{array}{c}\text { pp. } 279- \\
316 \\
37 \text { pages }\end{array}$ & $8.66 \%$ \\
\hline
\end{tabular}

Figure 2: Coverage of World War II in modern world history textbooks

\section{What key topics, events and theatres of war typically receive most prominent attention?}

Although the textbooks vary in their respective portrayals of the war, two areas of emphasis appear most salient. First, all four of the English textbooks principally view the war from a western European or British perspective. Accordingly generous coverage is given to various topics including Blitzkrieg and the German army's rapid advance through Europe, the fall of France, the evacuation at Dunkirk, the Battle of Britain, the Blitz, the Battle of the Atlantic, the bombing of Germany, D-Day and the Allied advance towards Berlin in 1944 and 1945. Three books devote on average 14 pages to the span of events listed above. In contrast, attention to the war in the Pacific constitutes four pages in Todd, two pages in Walsh, a few paragraphs in McAleavy, and is entirely absent from the book authored by Ferriby and McCabe. Similarly, although events on the Eastern Front receive attention in every book, their portrayal varies from a maximum of four pages in Walsh to a few sentences in both Ferriby and McCabe and McAleavy. Significantly, apart from mention of military campaigns in North Africa, no other aspect of war receives more than a few sentences. Overall, therefore, textbooks concentrate detailed attention on conflicts in Western Europe with the war in the Pacific, in North Africa, and on the Eastern front generally receiving very cursory portrayal. Involvement of peoples and nations beyond these geographical areas is almost entirely ignored in contemporary history textbooks.

In keeping with this parochial focus, the second feature of textbook treatment of World War II is the relatively consistent attention given to the impact of World War II on the home front in Britain. With the exception of McAleavy's book, which concentrates on the political and military aspects of war, the three other books generously portray the impact of the war on civilian life in Britain. Typically based around organizing questions such as 'How did the war change life in Britain?' (Ferriby and McCabe, p. 134) or 'How did the war affect civilians?' (Walsh, p. 298) all three books devote entire sections of between 11 and 15 pages to the subject. Common topics include evacuation, conscription, censorship, and propaganda, civilian defence, air raid precautions, food and rationing, and the experience of the Blitz. Each of the topics is impressively supported by an array of written sources and visual images including emotive photographs portraying, for example, evacuees or properties devastated by bombs, propaganda posters, oral histories, diary entries, and personal recollections. 
Of note, three textbooks give special attention to the role of women in war. Each book on average devotes two pages to the topic providing numerous examples of how women contributed to the war effort. The textbooks acknowledge that more than seven million British women, eight times the amount of the First World War, were employed in various capacities including the Women's Land Army, the munitions industry, the civil service, and the armed forces. Significantly, although issues associated with equality and changing social attitudes towards women are raised in some textbooks, issues of racial equality remain strikingly absent.

\section{How, in what way, and to what extent are the experiences of peoples from the Empire and Commonwealth portrayed in textbook narratives and photographic representations?}

For the most part history textbooks ignore the contributions and experiences of peoples from the Empire and Commonwealth during the Second World War. Despite the fact that Britain drew on the resources and support from all reaches of the Empire, typically reference is made solely to 'British forces', 'British victories', and 'British troops'. Where reference is broadened to include military activities with other nations, the term 'the Allies' frequently is employed. Abundantly clear, however, is that 'the Allies' refers to US, British, and less frequently, Soviet collaboration and rarely includes the scores of other nations involved in the global conflict.

Accordingly, Ferriby and McCabe make no mention of any nations beyond these three allied powers and their principal adversaries: Japan, Italy, and Germany. Similarly, except for one fleeting reference to Canadian involvement in the D-Day landings, McAleavy's text completely ignores the contributions of peoples from the Empire, Commonwealth, or indeed any other part of the world. Allan Todd's, The Modern World, is also parsimonious in its attention to the contributions of other nations and peoples. According to Todd, the war in Western Europe is a British and US affair; Italian and German troops are defeated in North Africa by the British; and despite a single reference to Australian troops and 'British and imperial forces', success in the Pacific largely occurs as the result of American military strength. Furthermore, although reference is made to Japanese conquests in Burma, Singapore, Malaya, and the impending threat to 'the important British colony of India', (p.165) no mention is made to the significant number of troops from Africa, India, New Zealand, Australia, and other nations who gave their lives ensuring the eventual defeat of the Japanese army.

Ben Walsh's, GCSE Modern World History, is slightly more sensitive to the involvement of other nations. Occasional reference is made to forces from 'Britain and the British Commonwealth and Empire'. Three sentences also are devoted to the importance of Canada's entry into the war, and Australian troops are credited with the defeat of Japanese forces in New Guinea in August 1943. In particular one paragraph stands out:

The conflict between the Allies and Japan was fought over a vast territory and involved millions of American troops as well as troops from Britain, India, Australia, and New Zealand. Some 120,000 Africans also fought for the Allies in the Burma campaign. India provided over 2.5 million men and women for the armed forces and spent a staggering 80 per cent of its wealth in 1943-44 on the war effort (p. 295).

This acknowledgment of the involvement of other peoples marks a refreshing departure from convention. Unfortunately the paragraph is remarkable for its rarity. Indeed these three sentences stand in woeful isolation against the more than 120 pages of text analysed in this study. Furthermore, despite Walsh's acceptance that the war reached beyond the narrow confines typically portrayed in most textbooks, 
the overall impression one forms from reading his book is that the war principally was a conflict between on the side, Germany and Japan and on the other, Britain, the USA, and the Soviet Union. Without question, references to the involvement of individual nations within the Empire and Commonwealth are severely restricted.

If narrative portrayals of people from the Empire and Commonwealth are rarely included in textbooks, visual representations prove little better. A striking feature of contemporary history textbooks is that they are visually appealing and colourful with narrative text typically occupying less than fifty percent of page content. Unlike textbooks produced in previous generations, textbooks today are adorned with maps, graphs, diagrams, photographs, pictures, cartoons, and posters. Likely these powerful visual sources play a significant role in shaping students' consciousness of the past. Analysis of photographic portrayals contained in the four textbooks, however, further illustrates how textbooks entirely ignore the involvement of peoples from the Empire and Commonwealth.

Fig. 3 below shows the number of photographic images contained within chapters relevant to the Second World War in each of the four books. It also shows the amount of times peoples of colour from the Empire and Commonwealth appear in these photographic representations.

\begin{tabular}{|l|l|l|l|l|}
\hline Author(s) & Principal Title & $\begin{array}{l}\text { Total Pages } \\
\text { Analysed }\end{array}$ & $\begin{array}{l}\text { Photographic } \\
\text { Representations } \\
\text { of the Second } \\
\text { World War }\end{array}$ & $\begin{array}{l}\text { Photographic } \\
\text { Representations } \\
\text { of People of } \\
\text { Colour From the } \\
\text { Empire and } \\
\text { Commonwealth }\end{array}$ \\
\hline $\begin{array}{l}\text { David Ferriby \& } \\
\text { Jim McCabe }\end{array}$ & $\begin{array}{l}\text { Modern World } \\
\text { History }\end{array}$ & 26 & 10 & 0 \\
\hline Tom McAleavy & $\begin{array}{l}\text { Modern World } \\
\text { History }\end{array}$ & 20 & 16 & 0 \\
\hline Allan Todd & $\begin{array}{l}\text { The Modern } \\
\text { World }\end{array}$ & 38 & 29 & 0 \\
\hline Ben Walsh & $\begin{array}{l}\text { GCSE Modern } \\
\text { World History }\end{array}$ & 37 & 31 & 0 \\
\hline
\end{tabular}

Figure 3: Photographic Representations of Peoples of Colour From the Empire and Commonwealth

As can be seen, out of a total of 86 photographic representations in the textbooks not one image portrays peoples of colour from the Empire and Commonwealth.

Overall, therefore, narrative and photographic analysis of the four textbooks demonstrates that representations of people from the Empire and the Commonwealth are woefully limited. In some textbooks they remain entirely absent; in others they often appear without context or explanation. Significantly, in the scores of representations of troops and civilians affected by the war in England only the experiences of white people are captured; as people of colour remain invisible. Given that many researchers have argued that textbooks have a powerful impact on how students come to know and understand the past (e.g., Foster \& Crawford, in press; Schissler \& Soysal, 2005; Marsden, 2001; Hein \& Selden, 2000; Apple \& Christian-Smith, 1991) it is reasonable to ask whether such narrow and limited representations of the Second World War are acceptable. Based on an analysis of relevant historical scholarship, the next section focuses on the experiences of colonial peoples during World War II. In so doing it raises serious questions about the continued failure of contemporary history textbooks to draw on this important historical record. 


\section{The British Empire and Commonwealth during World War II: The Historical Record}

\section{Scope of British Empire and Commonwealth}

At the beginning of the twentieth century the British Empire -- formed after 300 years of trade, conquest, and settlement, -- represented the world's most influential and powerful political and economic entity. At the outbreak of the Second World War the Empire held sway over a population approaching 500 million people, approximately a quarter of the world's population, and claimed more than 30 million square kilometres, equivalent to more than 20 per cent of the world's total land area. Its reach, power, and influence were unparalleled. The experience of nations living under the shadow of British imperialism varied considerably. Canada (1867), Australia (1901), New Zealand (1907) and South Africa (1910) enjoyed 'Dominion status' which ensured that through 'full internal self-government' (Perry, 1988, p. 124) a degree of autonomy from Britain existed. By contrast on the Indian sub-continent, in the Caribbean, and in most African colonies the wishes of the colonials largely proved subservient to the needs of the mother country. Indeed, whereas most British colonies were not consulted when Britain declared war on their behalf in September 1939, for the most part each Dominion individually decided when and how they would enter the war.

Although primary attention in this study is accorded to the 'hidden histories' of peoples from Africa, India, and, to a lesser degree the Caribbean, recognition should be afforded to the contributions of other members of the Commonwealth, especially those from Canada, Australia, and New Zealand. Particularly, as the previous section has illustrated these countries receive only fleeting treatment in most English history textbooks.

\section{Australia, New Zealand, Canada \\ Despite some shared concerns that British war strategists did not always consider the perspectives of the Dominion powers, Canada, New Zealand, and Australia generally were prepared to sacrifice enormous resources and military personnel to the Allied cause. Whether out of a sense of mutual interest or sentimental loyalty, when war broke out in Europe each nation immediately took sides with the British forces. As early as December 1939, for example, Canadian troops were despatched to Europe and in January 1940 Australian and New Zealand forces bolstered military commitments in the Middle East. By war's end these three nations had made vital contributions in each the three major theatres of war: Europe, North Africa, and the Pacific.}

In all, more than 200,000 New Zealand men and women served in the armed forces during the war. Of these 140,000 were despatched overseas largely to fight in campaigns in the Middle East and Italy. In total 11,625 sacrificed their lives during the Second World War. The contribution of Australian forces to the global conflict also was significant. During 1940-41 Australian troops served in campaigns in Egypt, Libya, Syria, Palestine, Crete, Greece, Malaya and Singapore. After repelling menacing advances by the enemy in Europe and the Pacific, by 1942 Australian forces had contributed impressively to Allied successes on a range of battlefronts including the deserts of North Africa, the jungles of Papua New Guinea, and the seas of the Pacific Ocean. Furthermore, The Royal Australian Navy played an important and diverse role in the Mediterranean Sea and the Indian Ocean. At the peak of the war, out of a population of seven million more than 500,000 served in the armed forces with hundreds of thousands more engaged in munitions, or building roads and airfields. In total Australian battle casualties amounted to 72,814 .

Canada's involvement in World War II was equally impressive. Serving in every major theatre of war Canadian troops witnessed action in, for example, Hong Kong, 
Sicily, Italy, and North Western Europe. Canadian forces also stood on vital guard duty in Britain during the period of greatest threat of German invasion and Canadian naval vessels proved invaluable during the vital Battle for the Atlantic. Most notably Canadian forces made a huge contribution to the D-Day landings of June 1944 and the subsequent Allied advances into central Europe during 1944 and 1945. At its maximum strength in 1943 Canadian armed forces amounted to half a million, of whom 43,000 tragically were killed in combat.

\section{Africa, India, and the Caribbean during World War II}

The involvement of troops from the Empire and Commonwealth became particularly expedient after initial military successes of the Axis powers had closed off the Mediterranean to the British. Re-establishing links and supply routes to the Middle East, India, and East Asia were critical to Britain's strategic success. Significantly, therefore, Indian and African forces substantially reinforced troops from Britain's Dominions. As the war gathered momentum the contribution of these colonial troops assumed even greater significance. Unfortunately, however, as illustrated earlier, history textbooks typically overlook the role that these nations and peoples played during the Second World War. Sherwood and Spafford (1999) similarly have argued that 'British school history is nearly always silent about the participation of black people in the Second World War...The war, so resonant in the British consciousness, is not recognised as being a black British story as much as it is a white one' (p. 1). Accordingly, in this section close attention is paid to diverse and complex wartime contributions, experiences, and perspectives of non-white colonial peoples.

Raw figures alone suggest the undeniable contributions made by colonial troops. Despite their commonplace absence in textbooks, in reality approximately 500,000 Africans, more than 7,000 Caribbean people, and a total of 2.5 million Indians fought for Britain during the Second World War (Sherwood \& Spafford, 1999; Furedi, 1999; Perry, 1988; Killingray, 1986). In total 170,000 Commonwealth men and women lost their lives or went missing as a result of the war (Somerville, 1998). Colonial troops saw service in military campaigns across the globe. During the course of the war, for example, the Fifth Indian Division fought against the Italians in Sudan, the Germans in Libya, and the Japanese in Burma, Malaya and Java (Visram, 1986).

\section{Recruitment and support}

The attitudes of colonial troops and citizens to the war were diverse and complex. Moreover, as historian David Killingray (1986) has noted, 'African reactions to military service are largely unrecorded' (p. 82). Nevertheless, available evidence suggests that opinion and attitudes varied considerably. Some, like Nigerian Chief Anthony Enahoro who declared, 'We prayed for British victory... we accepted the slogan 'We fight for Freedom' quite literally' (Sherwood \& Spafford, 1999, p. A4), considered loyalty to the British cause a natural and desirable state of affairs. Others were less enthusiastic. Some saw no distinction between Nazism and imperialism and wondered, 'If this was their war or Britain's, a global response to a deadly threat or a white man's colonial exercise' (Somerville, 1998, p. xviii). Significant elements in India were reluctant to fight for the British. Indeed, through its 'Quit India' programme and a campaign of civil disobedience, the influential Nationalist Congress Party proved fierce opponents of British rule and British military directives (Fryer, 1989; Visram, 1986). Many colonial citizens went to war for practical or personal reasons. For example, some went for adventure, to acquire new skills, or to enjoy the social and welfare benefits the military had to offer (Killingray, 1986; Oliver and Atmore, 1981). Others went for economic reasons. Accordingly, historian F. W. Perry (1988), who concluded that Indian enthusiasm for the war was 'neither unanimous nor consistent', also remarked that, as most of the Indian army originated from rural communities, 'when farming was prosperous recruitment tended to decline and vice versa. (p. 117). 
What is clear is that after initial reservations, the British government recognised the need for military conscription throughout its colonies. Whitehall also appreciated the important role that propaganda would have to play in encouraging loyalty and commitment from its imperial subjects. Revealingly a British Government propaganda directive of 1944 emphasised that 'the aim must be to present a picture of the moral and material strength of Britain and the Empire designed to arouse not only admiration and goodwill but also a sense of pride in membership of the Empire' (Sherwood and Spafford, 1999, p. B16). Arguably sustained and intensive attention to propaganda in the colonies offers some indication of British concerns about the level of colonial opposition or indifference to the war.

\section{African nations during World War II}

Whether willing or unwilling the contributions made by the peoples of the British Empire and Commonwealth proved very significant in the war effort. For example, the commencement of active war on the African continent soon swelled the number of regiments in both East and West Africa. In response to demands for personnel in East Africa and by the emerging threat of being surrounded by potentially hostile Vichy French territory in the second half of 1940, West African forces expanded to four times their pre-war size (Perry, 1988). In East Africa defence forces were established in Uganda, Tanganyika, Nyasaland and Kenya. Following Italian entry into the war in 1940, African forces were instrumental in the occupation of Italian East Africa and further expanded operations to include active serve in Somaliland, Madagascar, Mauritius, Seychelles and the Middle East (Perry, 1988). With the defeat of the Axis powers on the African continent in 1942 imperial authorities reevaluated their prejudiced and traditional position of using African soldiers only on African soil. The expedience of war caused a radical shift in strategic thinking (Killingray \& Rathbone, 1986) which resulted in African troops being deployed to Ceylon and then to Burma in order to fight the Japanese. African troops also fought in the Mediterranean campaign and in the Allied advance through Italy from 19431945. In all more than 160,000 Africans were sent abroad to fight.

A vital aspect of the contributions of Africans to the war was the huge numbers of people recruited for military labour. As David Killingray's (1986) exhaustive study of labour mobilisation in British colonial Africa during the war graphically illustrates the 'vast majority' of army recruits were enlisted as non-combatant 'labourers in uniform'. These men originated from every colonial territory and 'served as labourers on docks, in stone quarries, building fortifications and for general construction work'. In addition non-combatants were employed as signallers, fire fighters, lorry drives, pioneers, porters, carriers, as well as performing garrison duties. Indeed, although some scholars dispute the primacy of his claim, Killingray concluded that Africa's greatest contribution to the war 'was in the steady supply of military labour that substituted for European and American troops in the Middle East and North Africa campaigns' (p. 90).

\section{India during World War II}

When war broke out in Europe in September 1939 fewer than 200,000 personnel served in the Indian army. Soldiers were largely drawn from agricultural communities and the army remained an 'unmodernised force' (Perry, 1988). By the war's end, however, more 2.5 million men and women were in service and the Indian army and the Royal Indian Navy had made a significant contribution to the combined Allied victory (Perry, 1988, p. 117).

Prior to the breathtaking advance of the Japanese army in 1942, Indian troops committed to overseas service principally acted in supporting roles in Egypt, Malaya, Iraq, the Persian Gulf, and Burma. After 1942 however India became deeply involved in the war as the nation's orientation shifted to India's eastern front. Initially 
Indian troops shared in Allied setbacks in Malaya and Burma and, when Singapore fell in February 1942, tens of thousands of Indian troops were captured by the Japanese. By 1943, however, Indian troops served under Mountbatten's ultimately successful South East Asia Command and 'in early 1944 the Seventh Division's heroic stance at Kohima broke the force of the Japanese advance on Assam, and thereafter they shared in General Slim's triumphant return to Burma' (Spear, 1979; $p$. 216). After defeating the Japanese, Indian forces were the first Allied troops in Thailand, Indo-China, and the western islands of the Dutch East Indies (Perry, 1988).

India's contribution to the defeat of Japanese forces in the east additionally was matched by military service to the west. Indian troops shared in the impressive defeat of Italian and German forces in North Africa and vigorously participated in campaigns in Iraq, Syria, and the Persian Gulf. Furthermore, Indian involvement in Italy increased the size of British participation in the area by fifty percent.

Significantly despite common dissatisfaction with continued British rule in India, Indian military personnel typically served with commitment and distinction. As historian Percival Spear (1976) noted, 'Though the Indian heart was not in the war, the Indian war record is nevertheless impressive...[and] the army itself had a distinguished record' (p. 215). As a measure of their bravery Indian service personnel received 4,000 awards for gallantry and 31 Victoria Crosses (Sherwood, 2001) and the Indians were reputed to have 'among the best troops turned out by either side.' (Spear, 1979, p. 215). In total an estimated 36,000 Indian troops were killed or reported missing in action during World War II, with a further 65,000 wounded. Little doubt remains that India's military contribution to the war was particularly important at a time when British resources were stretched to their limit. Indeed historian F. W. Perry (1988) concluded that 'without the Indian Army Britain would have been quite unable to meet her many commitments in the Middle East and Far East' (p.120).

\section{The Caribbean during World War II}

In terms of numbers, size, and scale the involvement of the Caribbean islands could never match the contributions made by Indian and African forces. Nevertheless the Second Word War was very real to West Indian people who, like their European counterparts, concerned themselves with blackouts, air raid shelters and the need for a robust home defence. The disturbing immediacy of the war is illustrated, for example, by the reminiscences of one Jamaican who noted how,

Down in Kingston town, at a place they call Parade, they had two lists put up - a list of men reported missing and a list of men reported dead. And that list would go on and on...Sometimes you'd go and see the name of your cousin; you'd go back a few days later and see your friend's brother reported dead' (Somerville, 1998, p. 174).

In the early years of war Caribbean involvement principally was devoted to guarding the ports, constructing military installations, and securing strategic locations, such as the extensive oil installations in Trinidad. However, with US entry into the war and the increasing German U-boat offensive, British colonies in the West Indies came under increasing threat. As a result, in January 1942 a full-time battalion was mobilised in Jamaica and another in Guyana with further expansion, including the creation of the North and South Caribbean forces, occurring throughout 1943. Thousands of Caribbean men and women joined local home commands including 1287 people who served in the Trinidad Royal Naval Volunteer Reserve.

Although more than 6,000 Caribbean personnel were recruited by the RAF principally as ground crew, West Indian troops did not see extensive overseas service until late in the war. Thus, in September 1944 the 1,200 strong Caribbean regiment, who had received military training in the United States, arrived in Italy before joining garrison 
forces in Middle East (Sherwood \& Spafford, 1999; Perry 1988). Some 30 West Indians served as aircrew and in total 90 Caribbean men received military decorations, including 7 distinguished service orders and 64 DFC's. Accordingly, although the numerical contributions of military personnel from the Caribbean did not rival those of many other nations who participated in the war, the achievements of West Indian men and women were not without consequence. Certainly, for history textbooks to leave their role unrecognised is not only to ignore the historical record but also to deny the sacrifice made by the hundreds of Caribbean people who were killed or wounded during the Second World War.

\section{War beyond the military}

The role of the colonies in World War II extended well beyond the actions of military personnel. In particular Britain exploited its relationship with its colonies in two key ways. First, the colonies offered supply centres and bases for the armed forces. For example, more than 100,000 troops passed through West Africa during the war and countries like Gambia, Sierra Leone, the Gold Coast (Ghana) and Nigeria served as staging posts and strategically important military bases. Aircraft desperately needed for campaigns in the Middle East and North Africa initially entered the continent via West Africa. In addition, once use of the Suez Canal was ruled out, West African ports serviced and supplied allied shipping on their way to India and beyond (Sherwood and Spafford, 1999; Killingray and Rathbone, 1986; Spear, 1976). In east Africa vast amounts of supplies and material were moved north from Kenya to Egypt along the Africa Line of Communication route. Here, Egypt, under British control throughout the war, operated as the focal point for Middle East command (Killingray and Rathbone, 1986). Similarly while India became an important supply centre to campaigns in the Middle East and the Pacific, after 1940 US bases also were established and expanded in the West Indies (Sherwood and Spafford, 1999; Perry 1988). Such developments demanded that huge numbers of colonial workers were pressed into service in, for example, construction, supply, and maintenance (Killingray, 1986).

The second way that Britain exploited its colonies was through the widespread acquisition and use of raw materials, foodstuffs and resources produced by its imperial subjects. From the colonies came vital agricultural supplies of sisal, maize, wheat, tea, sugar, rubber, jute and cotton. In addition, although the British largely prohibited the development of industry in its colonies, it nevertheless took advantage of the Empire's rich mineral wealth in bauxite, iron, steel, manganese, tin, coal, timber, gold and diamonds (Sherwood \& Spafford, 1999; Killingray \& Rathbone, 1986; Spear, 1976).

Abundantly clear is that Britain's increasing thirst for materials, foodstuffs and manpower saw to it that colonial economies were continuously subverted and exploited. British officials showed little or no concern for local interests as they instigated ruthless price controls, coerced colonial labour, and unapologetically dictated colonial economic policy. Overall the war exacted a heavy economic price on many African colonies. Similarly, India, which diverted more than $80 \%$ of its annual budget to the war effort, and the Caribbean islands extensively shared in the huge and intolerable economic cost of war.

\section{Racism in war}

Despite the impressive involvement of colonial troops in World War II textbooks typically remain silent on the exploitation of colonial people, the endemic racism experienced by many, and the personal and gripping stories of individuals who sacrificed their lives for the Allied cause. Both in Britain and in the Empire little doubt exists that the Second World War was fought in a climate of 'stark racial prejudice' (Somerville, 1998 p. xviii). The unapologetic discrimination of people of colour in 
both civilian and military life was an uncomfortable and ubiquitous feature of the war years (Fryer, 1984). 'Black men were not even permitted to lie alongside the white corpses of their fellow men,' historian Christopher Somerville noted, and 'some were issued with spears and clubs, rather than rifles and grenades' ( $p$. xviii). Colonial troops routinely received inferior rations, lower pay, and discriminatory treatment. Furthermore it proved almost impossible for black troops to advance in rank and status. Significantly, no professionally trained black officer was established in the British army and, as one Kenyan soldier complained, 'an African's rank was meaningless to British soldiers' (Sherwood \& Spafford, 1999, p. 23).

Britain's military planners also were exceedingly keen to avoid any circumstance in which black or Indian troops might embrace 'ideas above their station'. As Frank Furedi (1999) noted, 'in one form or another matters of race had become integral to imperial decision making' (p. 188). As such the War Office proved reluctant to allow African troops to serve in Europe and Whitehall planners wanted to avoid any situations in which colonial troops could be 'contaminated with unacceptable ideas' held by African-American troops, thus 'subverting the existing racial balance of the Empire' (Furedi, 1999, p. 188). Unquestionably the war and its aftermath led both to an irreversible crisis in the culture of imperialism and a severe blow to white prestige. In this climate few in the British government wanted to exacerbate the problem by bringing colonial troops into contact with peoples who might fuel their aspirations. Thus, the maintenance of a status quo in which everyone knew 'their place' determined British imperial policy during the war (Fryer, 1984).

\section{Significance of World War II for Britain's Former Colonies}

As the textbook analysis illustrates the significant wartime contributions of colonial peoples remains largely unrecognized. Similarly, few textbooks see fit to examine how the war affected the future of Africa, India, and the Caribbean post- 1945. Typically textbooks move from selected coverage of World War II to the emergence of the Cold War in Europe. Once again, the important history of colonial people routinely remains unexplored. The impact of war on colonial people was, however profound and far-reaching. Historians Oliver and Atmore (1981) argue, for example, that 'the Second World War is the great turning point in the history of modern Africa', noting that moves to end colonial rule which had been unhurried at the beginning of the century became 'uncontrollable by the end of the war' (p. 33). Similarly, moves to independence in the Caribbean and the liquidation of the British Empire in India in 1947 were heavily influenced by the circumstance and consequences of war.

Despite the cursory attention give to these events, the war and its impact on British colonies unquestionably has significance for British schoolchildren for many reasons, of which three stand out. First, the end of the war marked a significant shift in the power and prestige of the British Empire. With the emergence of USSR and USA Britain's place in the modern world was re-examined and recast. Similarly Britain's relationship with the peoples of the Commonwealth had to be given sensitive and thoughtful consideration. Secondly, as the nations of Africa, India and the Caribbean enjoyed increasing independence new opportunities and challenges emerged. Today, these nations account for a significant proportion of the world's population and as such appreciating their histories and experiences forms a vital aspect of understanding the contemporary world. Third, post war emigration from the colonies to the United Kingdom offered a new dimension to the continued interaction between different peoples of the Commonwealth and Empire. Thus, an informed and richer understanding of the historical experiences of immigrants to Britain allows for a more thoughtful appreciation of Britain's modern multicultural society (see, Visram, 1994). 
Given these reasons and given the extensive contribution that people from the colonies made to war effort the question arises: why are their histories so often ignored or underrepresented in history textbooks?

\section{Why are the histories of people from the Empire and Commonwealth so often ignored or underrepresented in history textbooks?}

First and foremost, school history in England is heavily influenced by prescribed curriculum content. The contemporary history curriculum, however, does not represent a collection of value free, objective, and neutral knowledge. Rather the history curriculum has emerged as a result of generations of competing ideological, educational, and sociological influences. A powerful force in determining the history curriculum in England has been the weight of tradition. As many academics have demonstrated for more than a 100 years history teaching in England has had a distinctively Anglo-centric, nationalistic and conservative flavour (Marsden, 2001; Dickinson, 2000; Sylvester, 1994; Chancellor, 1970). Influenced by what Grosvenor (1997) refers to as 'the discourse of Empire' (p.188) this 'great tradition' of history teaching has ensured that generations of schoolchildren in England typically have been exposed to the transmission of a limited national heritage (Sylvester, 1994). John Slater's (1988) parody of the great tradition offers an illuminating insight into its central tenets:

Content was largely British, or rather Southern English; Celts looked in to starve, emigrate or rebel; the North to invent looms or work in mills; abroad was of interest once it was part of the Empire; foreigners were either, sensibly, allies, or, rightly, defeated. Skills -- did we even use the word? -- Were mainly those of recalling accepted facts about famous dead Englishmen, and communicated in a very eccentric literary form in examination-length essay. It was inherited consensus, based on largely hidden assumptions (p. 1).

Without question over the past twenty-five years the 'great tradition' in history education has encountered a serious challenge from advocates of what has loosely been termed 'new history'. In particular the influence of the Schools History Project with its emphasis on history as a form of knowledge (rather than just a body of knowledge) and increased attention to social history has seen some important changes in pedagogic practice in many schools throughout the country (see, Haydn, 2001; Dickinson, 2000; Sylvester, 1994; Phillips, 1988). Nevertheless, despite these significant changes it is important to recognise that in terms of curriculum content history teaching in England remains constrained by limited and narrow perspectives on the past.

To understand why this should be one only has to look at the fierce ideological battles that were fought over the history national curriculum during the late 1980s in which forces from the New Right proved highly influential (Crawford, 1996). Alarmed by what was perceived as the potentially corrosive influence of 'new history' in the original draft proposals for the history curriculum, published in July 1989, right-wing politicians powerfully asserted their authority. 'I was appalled,' remarked Prime Minister Margaret Thatcher. 'It put the emphasis on interpretation and enquiry as against content and knowledge. There was insufficient weight given to British history. There was not enough emphasis on chronological study' (Thatcher, 1993, p. 596). Echoing the concerns of others Conservatives, MP John Stokes also declared with exasperation 'Why can't we go back to the good old days when we learnt by heart the names of kings and queens of England, the feats of our warriors and our battles an the glorious deeds of the past?' (Haydn, 2001, p. 89). 
Not surprisingly given their huge political influence during late 1980s and early 1990s the views of the political right prevailed. Recognising the importance of controlling the past to promote selective national memories and to appease social and political agendas in the present, politicians understood the stakes were high. What emerged therefore was a national curriculum that chiefly celebrated the achievements of the dominant white majority and as Booth (1993) has argued, portrayed 'the whiggish story of the political and economic improvement of the great British people' (p. 79). Standing on what Rozina Visram (1994) has referred to as 'the twin pillars of patriotism and the transmission of a common cultural identity' (p.54) national curriculum mandates largely ignore the historically multicultural nature of British society. Indeed, emphasis on a narrow version of British history and the legacy of classical civilisations appear as hallmarks of the current curriculum.

The narrowness of the history national curriculum also is reflected in national assessment and examination provisions. Analysis of recent GCSE, AS and A2 history papers, for example, testify to the limited attention given to histories of ethnic groups and to the repeated focus on certain topics (e.g. Nazi Germany and World War II).

Influenced and constrained by these developments in curriculum and assessment publishers have responded by producing textbooks that address economic and ideological agendas. As Keith Crawford and I have argued elsewhere textbooks today are more than ever packaged and produced to respond to the demands of an increasingly state controlled education system and an increasingly profit driven textbook industry (Crawford and Foster, in press). Indeed by responding to the demands of the national curriculum, national testing systems, and other government initiatives, textbook publishing increasingly represents a form of ideological control in which certain knowledge is privileged over others. As Michel Apple and Linda Christian-Smith (1991) remind us, textbooks do not appear in a vacuum. Rather they are 'conceived, designed, and authored by real people with real interests' and are 'published with political and economic constraints of markets resources and power' (Apple \& Christian-Smith, 1991, p. 9). They emerge from what Raymond Williams has called a 'selective tradition' in which some knowledge is legitimated and other knowledge marginalized (Williams, 1989).

By definition, of course, selection involves de-selection and unfortunately because the Anglo-centric historical tradition remains pre-eminent, often neglected in textbooks are alternative narratives and discourses. Thus, the experiences of those who lie outside white history are marginalised or ignored. As Peter Fryer (1989) has persuasively argued,

By disguising or glorifying the true history of colonialism, and by writing black people out of British history, the official historians have marginalized and thus further oppressed those whose history they have distorted or concealed (p. xiii).

The inability of alternative versions of the past to penetrate mainstream narratives is also exacerbated by number of other factors. In particular, as curriculum time for history is increasingly squeezed by the claims of other subject areas, educators and textbook authors often argue the difficulty of covering what is perceived to be 'additional' subject matter. Moreover the lack of readily available educational resources on subjects beyond the mainstream, inadequate preparation on teacher education programmes (Siraj-Blatchford, 1993), and the failures of OFSTED and $\mathrm{QCA}^{2}$ to ensure that schools devote serious attention to issues of ethnic, cultural,

\footnotetext{
${ }^{2}$ OFSTED (Office for Standards in Education) is the government agency that inspects schools to ensure that the standards and policies of QCA are enforced. The QCA is the Qualification and
} 
and religious diversity all contribute to inadequate representations of the past in history classrooms (Sherwood, 1998).

Overall, people from the Empire and Commonwealth largely remain absent from portrayals of the Second World War because of a complex interrelationship of many factors. Specific to British history a central issue that permeates all these considerations is that, traditionally, the notion of what it is to be British is narrowly conceived. Britain today, as in the past, is a diverse multiracial, multilingual, and multicultural society. However, as lan Grosevonor (1997) has pointed out many critics, particularly those from the influential political Right, typically have construed British identity in narrow Anglo-centric terms. Accordingly, the experiences both of British citizens from various ethnic groups and of peoples from the Empire and Commonwealth have largely remained marginalised, decontextualised, or ignored in English history textbooks.

\section{Looking to the Future: Some recommendations for more inclusive history education}

Insufficient space is available here to detail the many educational changes required to make history education more inclusive. Nevertheless, three interrelated areas warrant close attention. First, it is important for all politicians, policy makers, educators and textbook authors to appreciate that identity, race, and nationhood are social constructions and that these constructions need to be re-cast as we enter the first decades of the twenty-first century. As has been argued, British identity traditionally has been shaped by adherence to a version of history which sees the achievements of white males as pre-eminent. Largely ignored are the stories, experiences, and achievements of people of colour. But as many critics have argued, since Roman times British history has been forged by the experiences of a complex mix of peoples from all over the world (Grosvenor, 1997; Visram, 1994; Fryer, 1989). To leave out their stories is to offer an 'incomplete understanding of British society and its development, its values and its culture' (Visram, 1997, p. 57). Similarly, because Britain has historically been connected to countries throughout the world, particularly those nations from the former British Empire in the Caribbean, Africa, and Asia, the histories of these peoples are inextricably linked together. It is essential therefore that history instruction reflects both the diversity of Britain and its interconnectedness with a complex array of other cultures and ethnic groups. Above all, the experiences of people of colour should not remain outside what has been regarded as mainstream history. Rather their stories should be intertwined, braided, and integrated into the rich and dynamic fabric of British and world history.

Second, and inexorably related to the point raised above, history educators and textbook writers must consider their application of curriculum content and avoid the damaging effects of 'mentioning' in which limited and ad hoc elements of the history and culture of minority groups are included without altering the central Anglo-centric story line. Rather than adding to a more sophisticated understanding of both British and world history, peppering the history curriculum with isolated and inadequate representations of ethnic groups will re-enforce notions that the stories of 'other' groups lie beyond the central story line of the nation. As American academic James Banks has argued 'the infusion of bits and pieces of ethnic minority groups into the curriculum not only reinforces the idea that [they] are not integral parts of...society, it also results in the trivialization of ethnic cultures' (Sleeter and Grant, 1991, p. 99).

More problematic is the current tendency to view history through the 'prism of racism' (Grosvenor, 1997) and include topics in the curriculum in which black people often

Curriculum Authority. This is the government body that oversees the operation and assessment of the National Curriculum. 
appear as victims or as problems. Teaching of the widely adopted Key Stage 3 study unit, Black Peoples of the Americas, for example, often serves to exacerbate this problem. Kay Traille's illuminating study of African-Caribbean students' perceptions of history demonstrate how many often feel uncomfortable and alienated when studying this topic, particularly because of its heavy emphasis on slavery. 'If the only story that black children can tell about slavery is of whites controlling the destiny of black people,' Traille remarked 'then they are limited with what they can do with the narrative, except personally identify themselves as victims or reject it.' According to Traille, what the students wanted was 'a history curriculum that included black people as part of the mainstream narrative, not a marginalised sub-section' (p. 176).

The third issue of importance is the need to ensure that relevant scholarship on the experiences of people of colour penetrates the educational system. History textbook authors, teacher educators, teachers, policy makers, exam boards, and government inspectors need to be more aware of the complex, rich and diverse stories that have existed in British and world history. In particular, history teachers need to take advantage of the current flexibility of the Key Stage $3^{3}$ history curriculum and approach history from a more inclusive, critical, and challenging perspective. Development in history education in recent decades with emphasis on history as a form of knowledge also provides opportunities for students to analyse and assess the construction of different and more inclusive accounts of the past.

Addressing and implementing these three recommendations poses a difficult challenge. In terms of understanding the Second World War it will require greater attention to the histories of ethnic groups within Britain and to peoples from the Empire, Commonwealth and beyond. Broader than this it will involve a reconceptualization of British identity, critical consideration of curriculum, pedagogy and instructional resources and a fierce commitment on the part of policy makers, the education establishment and, above all, teachers. If history education can go some way to embracing these three recommendations it will undoubtedly result in students having a more inclusive, more responsible, more exciting, and more worthwhile appreciation of our shared history.

\section{Acknowledgements}

The author would like to thank Marika Sherwood, of the Black \& Asian Studies Association and Honorary Senior Research Fellow at the Institute for Commonwealth Studies for her advice and critical commentary in the development of this paper.

\section{Correspondence}

Dr. Stuart Foster

School of Arts and Humanities

Institute of Education

University of London

WC1H OAL

s.foster@ioe.ac.uk

\footnotetext{
${ }^{3}$ Key Stage 3 is for pupils aged 11-14 years old (Key Stage 1: 5-7 years; Key Stage 2: 7-11 years; Key Stage 4: 14-16 years).
} 


\section{References}

Apple, M. \& Christian Smith, L., (eds) (1991) The Politics of the Textbook New York, Routledge.

Apple, M. \& Christian Smith, L., (1991) 'The Politics of the Textbook', in Apple, M. \& Christian Smith, L. The Politics of the Textbook New York, Routledge.

Booth, M. (1993) 'History', in King, A.S. \& Reiss, M.J. (eds) The Multicultural

Dimension of the National Curriculum London, Falmer Press.

Chancellor, V. E. (1970) History for their Masters: Opinion in the English History

Textbook, 1800-1914 New York, Augustus M. Kelley.

Crawford, K. A. (2000) 'Researching the Ideological and Political Role of the History Textbook: Issues and Methods', International Journal of Historical Learning Teaching and Research, 1, 1.

Crawford, K. A., (1996) 'A History of the Right: the Battle for National Curriculum History 1989-1994', in British Journal of Educational Studies, Volume 43: 12-24.

Crawford, K. A. \& Foster, S. J. (in press) 'The Political Economy of History Textbook Publishing in England', in Oxford Studies in Comparative Education.

Dickinson, A. (2000) 'What Should History Be?', in Kent, A. (ed) School Subject

Teaching: The History and Future of the Curriculum London, Kogan Page.

Foster, S. J. \& Crawford, K. A., (eds) (in press) What Shall We Tell the Children?

International Perspectives on School History Textbooks Greenwich, CT: Information Age Publishing.

Foster, S. J. \& Crawford, K. A., (in press) 'The Critical Importance of History Textbook Research', in Foster, S.J. \& Crawford, K.A. (eds) What Shall We Tell the Children? International Perspectives on School History Textbooks Greenwich, CT: Information Age Publishing.

Foster, S. J. \& Nicholls, J., (2005) 'America's Role in World War II: An Analysis of History Textbooks from England, Japan, Sweden, and the United States', in The Journal of Curriculum and Supervision, 20: 214-234.

Foster, S. J., (1999) 'The Struggle for American Identity: Treatment of Ethnic Groups in United States History Textbooks', in History of Education, 28: 251-279.

Foster, S. J. \& Rosch, R., (1997) 'Teaching World War I from Multiple Perspectives', in Social Education, 61: 429-434.

Foster, S. J., Morris, J. W., \& Davis Jr., O. L. (1996) 'Prospects for Teaching Historical Analysis and Interpretation: National Curriculum Standards for History Meet High School History Textbooks', in Journal of Curriculum and Supervision, 11: 367-385.

Foster, S. J. \& Morris, J. W., (1994) 'Arsenal of Righteousness: Treatment of the Atomic Bombing of Hiroshima in English and U. S. History Textbooks', in Curriculum, 15: 163-173.

Fryer, P. (1984) Staying Power: the History of Black People in Britain London, Pluto Press.

Fryer, P. (1989) Black People and the British Empire: An introduction London, Pluto

Press.

Furedi, F. (1999) 'The Demobilized African soldier and the blow to white prestige', in Killingray, D. \& Omissi, D. (eds) Guardians of Empire: The Armed forces of the Colonial Powers c. 1700-1964 Manchester, Manchester University Press.

Grosvenor, I. (1997) Assimilating Identities: Racism and Educational Policy in Post 1945 Britain London, Lawrence and Wishart.

Grosvenor, I. (2000), "History for the Nation': Multiculturalism and the teaching of history', in Arthur, J. \& Phillips, R. (eds) Issues in History Teaching London, Routledge.

Haydn, T. (2004) 'History', in White, J. (ed) London, RoutledgeFalmer.

Hein, L. \& Selden, M. (eds) (2000) Censoring History: History, Citizenship and Memory in Japan, Germany and the United States London, M. E. Sharpe. 
Killingray, D. \& Omissi, D. (eds) (1999) Guardians of Empire: The Armed forces of the Colonial Powers c. 1700-1964 Manchester, Manchester University Press.

Killingray, D. \& Rathbone, R. (eds) (1986) Africa and the Second World War London, Macmillan.

Killingray, D. (1986) 'Labour Mobilisation in British Colonial Africa for the War Effort, 1939-46', in Killingray, D. \& Rathbone, R. (eds) Africa and the Second World War London, Macmillan.

Marsden, W. (2001) The School Textbook: Geography, History and the Social Studies London, Woburn Press.

Nicholls, J. (2003) 'Methods in School Textbook Research', in International Journal of Historical Learning Teaching and Research, 3, 2.

Nicholls, J. \& Foster, S. J., (2005) "Interpreting the Past, Serving the Present': US and English Textbook Portrayals of the Soviet Union During World War II', in Ashby, R., Gordon, P. \& Lee, P. (eds) International Review of History Education, Volume IV. Oliver, R. \& Atmore, A. (1981) Africa Since 1800 Cambridge, Cambridge University Press.

Perry, F. W. (1988) The Commonwealth Armies: Manpower and Organisation in Two World Wars Manchester, Manchester University Press.

Phillips, R. (1998) History Teaching, Nationhood, and the State: A Study in Educational Politics London, Cassell.

Pingel, F. (1999) UNESCO Guidebook on Textbook Research and Textbook Revision Hanover, George Eckert Institute for International Textbook Research. Schissler, H. (1990) 'Limitations and Priorities for International Social Studies Textbook Research', in The International Journal of Social Education, 4: 81-89. Schissler H. \& Soysal, Y. (eds) (2005) The Nation Europe and the World: Textbooks and Curricula in Transition Oxford, Beghahn Press.

Sherwood, M. (1998) 'Sins of Omission and commission: history in English schools and struggles for change', in Multicultural Teaching 16: 14-20.

Sherwood, M. \& Spafford, M. (1999) Whose Freedom were African, Caribbean and Indians Defending in World War II? London, Savannah Press/BASA.

Sherwood, M. (2001) 'Colonies, Colonials, and World War II', at http://www.bbc.co.uk/history/war/wwtwo/colonies colonials 01.shtml. Siraj-Blatchford, I. (ed.) (1993) Race, Gender and the Education of Teachers Buckingham, Open University Press.

Slater, J. (1988) The Politics of History Teaching: A humanity dehumanised London, Institute of Education.

Sleeter, C. E. \& Grant, C. A. (1991) 'Race, class, gender, and disability in current textbooks', in Apple, M. \& Christian Smith, L. The Politics of the Textbook New York, Routledge.

Somerville, C. (1998) Our War London, Weidenfeld and Nicolson.

Spear, P. (1979) A History of India: Volume I/ London, Penguin Books.

Sylvester, D. (1994) 'Change and continuity in history teaching, 1900-93', in H.

Bourdillon, H. (ed) Teaching History London, Routledge.

Thatcher, M. (1993) The Downing Street Years New York, Harper Collins.

Tomlinson, S. (2001) 'Some success, could do better:' Education and race 19762000', in Phillips, R. \& Furlong, J. (eds) Education, Reform, and the State: Twentyfive Years of Politics, Policy, and Practice London, RoutledgeFalmer.

Traille, K. School History and Perspectives on the Past: A Study of Students of African-Caribbean Descent Unpublished thesis, Institute of Education, University of London.

Visram, R. (1986) Ayahs, Lascars, and Princes: Indians in Britain 1700-1947 London, Pluto Press.

Visram, R. (1994) 'British History: whose history?' Black perspectives on British history', in Bourdillon, H. (ed) Teaching History London, Routledge. 
Williams, R. (1989) 'Hegemony and the Selective Tradition', in de Castell, S., Luke, A. \& Luke, C. (eds) Language, Authority and Criticism: Readings on the School Textbook London, Falmer Press. 